\title{
Investigation and Nanomechanical Behavior of the Microconstituents of Al-Si-Cu alloy After Solution and Ageing Heat Treatments
}

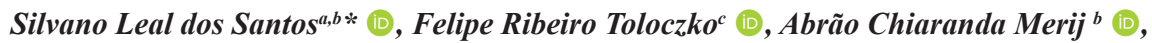 \\ Newton Haruo Saito ${ }^{b}$ (), Davinson Mariano da Silva ${ }^{b}$ (1) \\ ${ }^{a}$ Universidade Federal do ABC, Centro de Engenharia, Modelagem e Ciências Sociais Aplicadas, Santo \\ André, SP, Brasil \\ ${ }^{b}$ Faculdade de Tecnologia de São Paulo, Laboratório de Processamento e Caracterização de Materiais, \\ São Paulo, SP, Brasil \\ ${ }^{c}$ Faculdade de Tecnologia de São Paulo, Laboratório de Usinagem, São Paulo, SP, Brasil
}

Received: July 20, 2020; Revised: December 15, 2020; Accepted: December 20, 2020

\begin{abstract}
The effects of heat treatment on the microstructural evolution and mechanical behavior of $\mathrm{Al}-\mathrm{Si}-\mathrm{Cu}$ alloy were investigated. Solution heat treatment was performed at $500^{\circ} \mathrm{C} / 6 \mathrm{~h}$ and $540^{\circ} \mathrm{C} / 6 \mathrm{~h}$, followed by quenching in warm water at $60^{\circ} \mathrm{C}$. Lastly, artificial ageing treatment was performed at $160^{\circ} \mathrm{C} / 6 \mathrm{~h}$, $190^{\circ} \mathrm{C} / 4 \mathrm{~h}$ and $210^{\circ} \mathrm{C} / 2 \mathrm{~h}$. The microstructural evolution of the samples before and after heat treatments was analyzed by optical microscopy, scanning electronic microscopy (SEM) and Energy Dispersive Spectroscopy (EDS). Analyses revealed the presence $\mathrm{Al}_{5} \mathrm{FeSi}, \mathrm{Al}_{15}(\mathrm{FeMn})_{3} \mathrm{Si}_{2}, \mathrm{Al}_{2} \mathrm{Cu}$ and $\mathrm{Si}$ particles. The morphologies of the present phases were dependent on the heat treatment. Solution treatment at $540^{\circ} \mathrm{C} / 6 \mathrm{~h}$ resulted in significant softening of the alloy compared with the treated samples at $500^{\circ} \mathrm{C} / 6 \mathrm{~h}$. Vickers hardness analysis indicated that the hardness peak of the alloy after heat treatment was about $125 \mathrm{HV}$. Mechanical properties of different phases have been investigated by nanoindentation technique, which indicated that the highest hardness and modulus of elasticity were found for the $\mathrm{Si}$ particle, especially those distributed in the microstructures of the samples submitted to higher solution and ageing temperatures.
\end{abstract}

Keywords: Aluminum alloys, Intermetallic compounds, Heat treatments, Nanoindentation.

\section{Introduction}

The hypoeutectic Al-Si-Cu alloys present excellent mechanical properties, including a good strength versus weight ratio, which make these alloys excellent choices for automotive industries ${ }^{1}$. The $\mathrm{Al}-\mathrm{Si}-\mathrm{Cu}$ alloys in the as-cast condition present microstructures composed by primary aluminum matrix with predominantly dendritic grains and $\mathrm{Al}-\mathrm{Si}$ eutectic region ${ }^{2}$. The presence of elements as $\mathrm{Fe}, \mathrm{Cu}$, $\mathrm{Mg}$ and $\mathrm{Mn}$ in their chemical composition may promote the formation of intermetallic compounds as $\mathrm{Al}_{5} \mathrm{FeSi}, \mathrm{Al}_{15}\left(\mathrm{FeMn}_{3} \mathrm{Si}_{2}\right.$ and $\mathrm{Al}_{2} \mathrm{Cu}$ on the microstructures of the aluminum alloys ${ }^{3}$. Some intermetallics may be responsible for decreasing the mechanical properties on the materials. Some of Fe-rich compounds present needle-shaped morphology, which may cause material embrittlement by stress concentration ${ }^{4}$. However, the presence of other microconstituents contributes to improve mechanical properties. The presence of $\mathrm{Al}_{2} \mathrm{Cu}$ and $\mathrm{Al}_{15}(\mathrm{FeMn})_{3} \mathrm{Si}_{2}$ on the microstructure, promotes a good combination of strength and ductility in the alloys ${ }^{5}$.

Another alternative to obtain improved mechanical properties to $\mathrm{Al}-\mathrm{Si}$ alloys is the employment of solution heat treatment which promotes necking, fragmentation and spheroidization of eutectic Si particles, modifying the morphology from needle to globular-shapes, reducing

*e-mail: silvanoleal@fatecsp.br the detrimental effects of the former phase ${ }^{6,7}$. Wang et al ${ }^{8}$ observed the coarsening process of the Si particles in eutectic Al-Si alloy after solution heat treatment at $560^{\circ} \mathrm{C}$. According to Samuel et al. ${ }^{9}$, ultimate tensile stress and ductility are greatly enhanced after solution treatments during different periods of time, followed by ageing treatment at $150^{\circ} \mathrm{C}$ for $5 \mathrm{~h}$. Enhancement of the mechanical properties of the alloy studied in their work was attributed to the $\mathrm{Mg}_{2} \mathrm{Si}$ precipitation, dissolution of $\mathrm{Si}$ within the Al-matrix, and change in the $\mathrm{Si}$ particle morphology to spheroid shape. Thus, modification of the primary aluminum grains from dendrites to globular shapes, as well as changes of the Al-Si eutectic region are options found in the solution treatments.

Ageing treatments performed at higher temperatures and longer times promote the formation of Guinier-Preston (GP) zones that may act as precursors to nucleate and grow precipitates. On the other hand, ageing at low temperatures contributes to the delay of precipitates growth, resulting in the formation of a higher quantity of smaller particles, which enhances the strength of the alloy. Microhardness tests are utilized in Al-Si alloys after solution treatment and ageing to investigate the influence of the heat treatment parameters on the mechanical properties of the treated alloys. In previous literature $^{10,11}$, ageing treatment in $\mathrm{Al}-\mathrm{Si}-\mathrm{Mg}$ alloys lead to the formation of finer precipitates in the supersaturated primary 
Al matrix in Al-Si-Mg alloys, resulting in a good combination of strength and ductility. The hardening peak obtained in alloy under ageing treatment is related the formation of GP zones and precipitated phases in the microstructure. These phases play an important role in material strengthening due to the strong reduction of dislocation movements caused by semi-coherent and needle-shaped precipitates ${ }^{12}$.

The different phases formed in the microstructure of the $\mathrm{Al}-\mathrm{Si}-\mathrm{Cu}-\mathrm{Fe}$ alloys due to the presence of alloying elements need to be controlled and studied. The individual phases, such as primary Al, Fe-rich intermetallics and Si particles present different hardness and elastic modulus. Thus, the individual mechanical properties of each microconstituent contributes directly to the mechanical properties of the alloy $^{13,14}$. Fe-rich intermetallics, for example, may cause embrittlement of Al-Si-Cu alloys due their morphology ${ }^{15}$. Nanoindentation tests are, in this sense, a powerful tool to investigate the mechanical behavior of each individual phase. Nevertheless, there are few reports on hardness properties and elastic modulus of the intermetallic compounds and particles that constitute the microstructures of the Al-Si-Cu alloys ${ }^{16,17}$.

In spite of the relevant findings accumulated so far on the macrohardness behavior of Al-Si-Cu alloys, the concomitant effect of the solution temperature and ageing treatment on the hardness and elastic modulus response in each individual phase is rarely found in the literature.

In this sense, this work aims to investigate the mechanical behavior of the individual phases obtained from solution / ageing treatments. In order to achieve this goal, nanoindentation technique was employed to obtain hardness and elastic modulus of the following individual phases: Al matrix, $\mathrm{Si}$ particles and $\mathrm{Al}_{15}(\mathrm{FeMn})_{3} \mathrm{Si}_{2}$. We also correlate the mechanical properties found from nanoindentation tests to the solution temperature and ageing treatment. Finally, the mechanical behavior of the alloy is investigated and correlated to the individual contribution of each microconstituent.

\section{Experimental Procedure}

\subsection{Material and preparation}

The Al-Si alloy used in this work was the DIN EN AC 46000, widely utilized in automotive applications ${ }^{18,19}$. The alloy was melted in a $\mathrm{Si}-\mathrm{C}$ crucible at $720^{\circ} \mathrm{C}$, using a resistance furnace. The melted alloy was poured into a rectangular cross section metallic mold ( 2 × 4 × $25 \mathrm{~cm})$. Billets shape samples $(2 \times 2 \times 2 \mathrm{~cm})$ were obtained. The chemical composition of the alloy, shown in Table 1, was obtained by optical Emission Spectrometry (Spectrolab).

Samples were submitted to solution heat treatments, carried out at $500^{\circ} \mathrm{C}$ and $540^{\circ} \mathrm{C}$, both for 6 hours, and quenched in warm water at $60^{\circ} \mathrm{C}$. The samples were, afterwards submitted to ageing at $160^{\circ} \mathrm{C}, 190^{\circ} \mathrm{C}$ and $210^{\circ} \mathrm{C}$ holding at 6,4 , and $2 \mathrm{~h}$, respectively. The aged samples were cooled in air to room temperature. The thermal cycle for each stage of the T6 heat treatment is represented in Figure 1.

\subsection{Microstructural and microhardness analysis}

Differential scanning calorimetry (DSC) measurements under argon atmosphere were performed to evaluate the phase transformation temperatures of the alloy in the as-cast condition under cooling using a Setaram Setsys Evolution 1200 equipment with a sample weight of approximately $40 \mathrm{mg}$. Temperature was raised from room temperature up to $700^{\circ} \mathrm{C}$ at $10^{\circ} \mathrm{C} \cdot \mathrm{min}^{-1}$. After reaching this temperature, a cooling rate of $10^{\circ} \mathrm{C} \cdot \mathrm{min}^{-1}$ was applied to the molten alloy and the heat flux was measured during solidification back to room temperature.

Microstructure analyses were performed by optical microscopy (Zeiss, Axio) and scanning electron microscopy (Jeol, JCM 6000 Plus). For the microstructural analysis, samples were previously grounded with $\mathrm{SiC}$ abrasive paper up to 600 grit, polished with diamond paste up to $1 \mu \mathrm{m}$ and etched with Keller's solution $\left(0.5 \% \mathrm{HF}\right.$ in $\left.50 \mathrm{ml} \mathrm{H}_{2} \mathrm{O}\right)$ for $10 \mathrm{~s}$. $\mathrm{X}$-ray energy dispersive spectroscopy (EDS) was employed for the analysis of chemical composition of the phases and intermetallic compounds. High Resolution X-ray diffraction (XRD) was also employed to identify the microconstituents in the alloy (Bruker AXS D8).

Microhardness measurements were carried out in a Vickers microhardness tester (Mitutoyo, HM 210) with an applied load of $1 \mathrm{kgf}$. Hardness values were obtained from the average of seven indentation readings taken in each sample.

\subsection{Nanoindentation technique}

Nanoindentations tests were performed to access the mechanical properties of individual phases within the Al-Si alloy and correlate the results with the macroscopic behavior of the materials. Nanoindentation tests were performed in an Anton Paar Nanoindenter, model NHT3, operated in a continuous stiffness measurement mode, under 20 and $50 \mathrm{mN}$ loads, using a diamond Berkovich indenter.

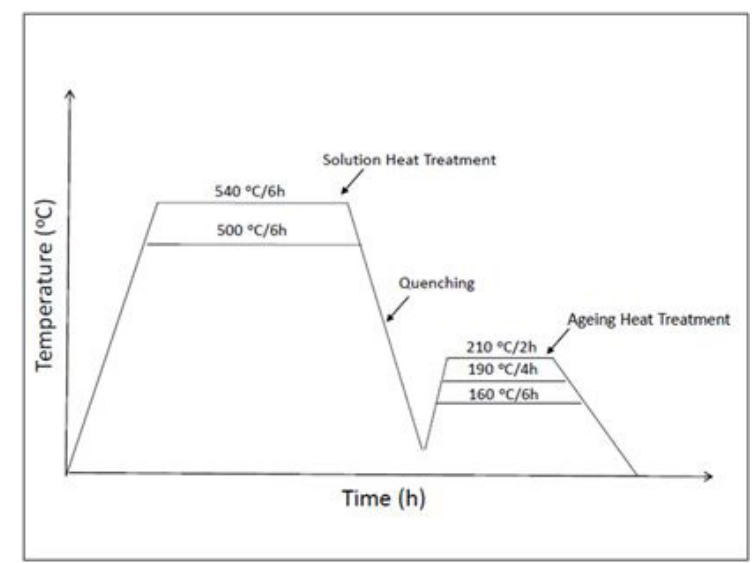

Figure 1. Thermal cycle employed during T6 treatment of the DIN EN AC 46000 alloy.

Table 1. Chemical composition of the Al-Si-Cu (wt \%).

\begin{tabular}{cccccccccccccc}
\hline $\mathrm{Si}$ & $\mathrm{Cu}$ & $\mathrm{Mn}$ & $\mathrm{Fe}$ & $\mathrm{Mg}$ & $\mathrm{Cr}$ & $\mathrm{Sr}$ & $\mathrm{Zn}$ & $\mathrm{Ni}$ & $\mathrm{Pb}$ & $\mathrm{Ti}$ & $\mathrm{Al}$ \\
\hline 10.35 & 2.11 & 0.14 & 0.78 & 0.13 & 0.02 & 0.01 & 0.63 & 0.04 & 0.07 & 0.03 & $\mathrm{Bal}$ \\
\hline
\end{tabular}


From load-displacement curves obtained from nanoindentation tests, we could obtain the nanohardness value, $H$, for each phase, according to the method of Oliver and Pharr $^{20,21}$ :

$\mathrm{H}=\frac{\mathrm{P}_{\mathrm{Max}}}{\mathrm{A}_{\mathrm{C}}}$

where $\mathrm{P}_{\mathrm{Max}}$ is the maximum indentation load and $\mathrm{A}_{\mathrm{C}}$ is the projected area of the hardness impression. The elastic modulus of each phase may also be retrieved from nanoindentation tests, as follows:

$\frac{1}{\mathrm{E}_{\mathrm{r}}}=\frac{1-v_{\mathrm{i}}^{2}}{\mathrm{E}_{\mathrm{i}}}+\frac{1-v_{\mathrm{s}}^{2}}{\mathrm{E}_{\mathrm{s}}}$

where $v_{\mathrm{s}}$ and $\mathrm{E}_{\mathrm{s}}$ are the Poisson's ratio and Young's elastic modulus of the individual phase, respectively; $v_{i}$ and $E_{i}$ are the Poisson's ratio and Young's elastic modulus of the indenter. For this work, $v_{\mathrm{i}}=0.07$ and $\mathrm{E}_{\mathrm{i}}=1141 \mathrm{GPa}$. $\mathrm{E}_{\mathrm{r}}$ is the reduced modulus,

$\mathrm{E}_{\mathrm{r}}=\frac{\sqrt{\pi}}{2} \frac{\mathrm{S}}{\sqrt{\mathrm{A}_{\mathrm{C}}}}$

where $\mathrm{S}$ is the slope of the load/indentation curve during the unloading cycle. The reduced modulus is a combination of effective contact between the indenter and the material test ${ }^{16}$.

\section{Results and Discussion}

\subsection{Thermal analysis}

The DSC curve of Al-Si-Cu alloy in the as-cast condition is shown in Figure 2. The exothermic peak centered at $\sim 505^{\circ} \mathrm{C}$ (peak 1) is related to the formation of the copper rich phase $\left(\mathrm{Al}_{2} \mathrm{Cu}\right)^{22}$. The peak centered at $\sim 552^{\circ} \mathrm{C}$ (peak 2) may be attributed to the solidification of the eutectics $(\mathrm{Si}-\alpha-\mathrm{Al})^{23}$ and $\mathrm{Fe}$-containing phase ${ }^{24}$. The peak centered at $\sim 577^{\circ} \mathrm{C}$ (peak 3 ) corresponds to the solidification of the primary $\alpha$-Al phase. Finally, the peak centered at $\sim 614^{\circ} \mathrm{C}$ (peak 4 ), indicates the presence of the primary Fe rich phase ${ }^{25}$.

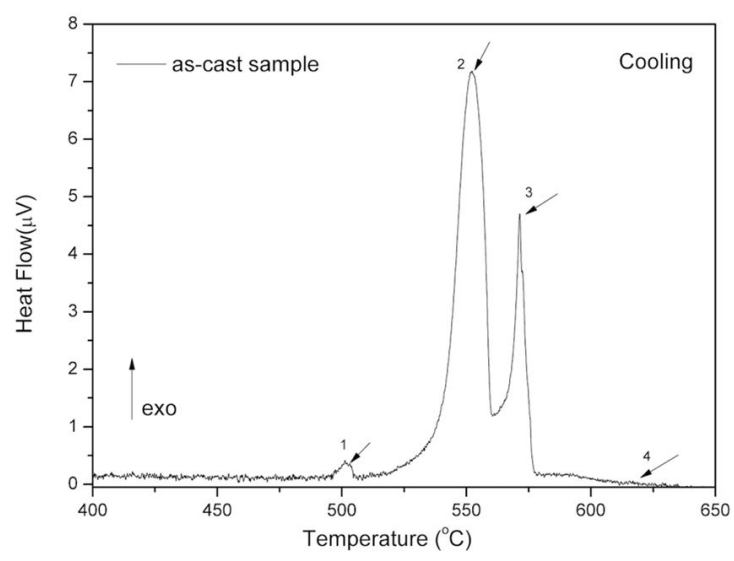

Figure 2. DSC curve of the Al-Si-Cu alloy in the as-cast condition obtained during cooling rate at $10^{\circ} \mathrm{C} / \mathrm{min}$.

\section{Microstructural Characterization}

The microstructural features of the as-cast sample are shown in Figure 3a. Si particles with needle-like morphology dispersed on $\alpha$-Al matrix are observed. Besides, the presence of $\mathrm{Al}_{5} \mathrm{FeSi}$ intermetallic phase with acicular shape was also noted. Acicular phases shown in the as-cast alloy are quite detrimental to the mechanical properties of the material, because the tips of these particles may act as stress concentrators $^{26}$. Similar microstructural features were also reported for as-cast Al-Si alloys ${ }^{27}$.

The microstructures of the samples submitted to solution treatments at $500^{\circ} \mathrm{C} / 6 \mathrm{~h}$ and ageing at $160^{\circ} \mathrm{C} / 6 \mathrm{~h}, 190^{\circ} \mathrm{C} / 4 \mathrm{~h}$ and $210^{\circ} \mathrm{C} / 2 \mathrm{~h}$ showed, sequentially, necking, fragmentation and spheroidization of eutectic Si particles. In this sense, the heat treatments caused a modification in Si particles, from acicular to globular shapes, when compared with the as-cast sample, as shown in the Figure 3b-d. Results showed that solution treatment was able to increase the distortion energy near curvature regions of the Si particles, causing quick fragmentation and spheroidization of eutectic Si particles $^{28}$. Spheroidization, by the other hand, occurs due to the reduction in the total interfacial energy, promoted by the instability of interfaces between two different phases. In a higher temperature, diffusion in the interface regions between Si particles and primary Al matrix is promoted, which favors the increase in the curvature radii reducing the free energy of the Si particles surface ${ }^{28,29}$. Solution treatment at $500^{\circ} \mathrm{C}$, in all ageing conditions proved, thus, to be adequate to reduce the detrimental effect of the acicular Si particles.

Figure $3 \mathrm{e}-\mathrm{f}$ shows the microstructures for the samples submitted to solution treatment at $540^{\circ} \mathrm{C}$. It is notable the occurrence of exaggerated growth of Si particles and $\mathrm{Al}_{5} \mathrm{FeSi}$ intermetallic compound. Al-Si alloys with silicon content near the eutectic composition usually exhibit long rod/acicular eutectic Si particles ${ }^{30}$. However, primary silicon particles with polyhedral shape were found in hypoeutectic Al-Si alloys after heat treatment at $540{ }^{\circ} \mathrm{C}^{31}$. This morphology is predominantly present in the microstructure eutectic matrix of cast hypereutectic Al-Si alloy ${ }^{32-34}$. In Figure $3 g$, a significant expansion of the eutectic region (Al-Si) was also noted, mainly after ageing at $210^{\circ} \mathrm{C} / 2 \mathrm{~h}$. Coarsening of the $\mathrm{Si}$ particles occurs in detriment of the acicular Si particles present in the eutectic region. This is in conformity to the fact that diffusion transport of silicon atoms is enhanced as temperature rises ${ }^{35}$. It was also noted the growth of Fe-rich particles distributed in the eutectic region, for the solution treatment at $540^{\circ} \mathrm{C}$ in all ageing temperatures, independently of the holding times. Menargues et al. ${ }^{36}$ observed the growth of eutectic Si particles in Al-Si alloys, during a short T6 treatment. The observed growth of the Si particles may be attributed to Ostwald ripening phenomenon ${ }^{37}$, that occurs when the particles sizes are greater than the critical volume, growing at the expense of smaller particles. Si particles coarsening for solution treatments above $500^{\circ} \mathrm{C}$ was already reported in the literature ${ }^{38-40}$.

SEM images shown in Figure 4a-c, show the microstructures for samples in the as-cast condition, as well as for samples submitted to solution heat treatment at $500^{\circ} \mathrm{C}$ and $540^{\circ} \mathrm{C}$. EDS microchemical analysis exhibited the presence of Si particles and the eutectic $\mathrm{Al}_{2} \mathrm{Cu}+\mathrm{Si}$. Besides, iron-rich intermetallics 


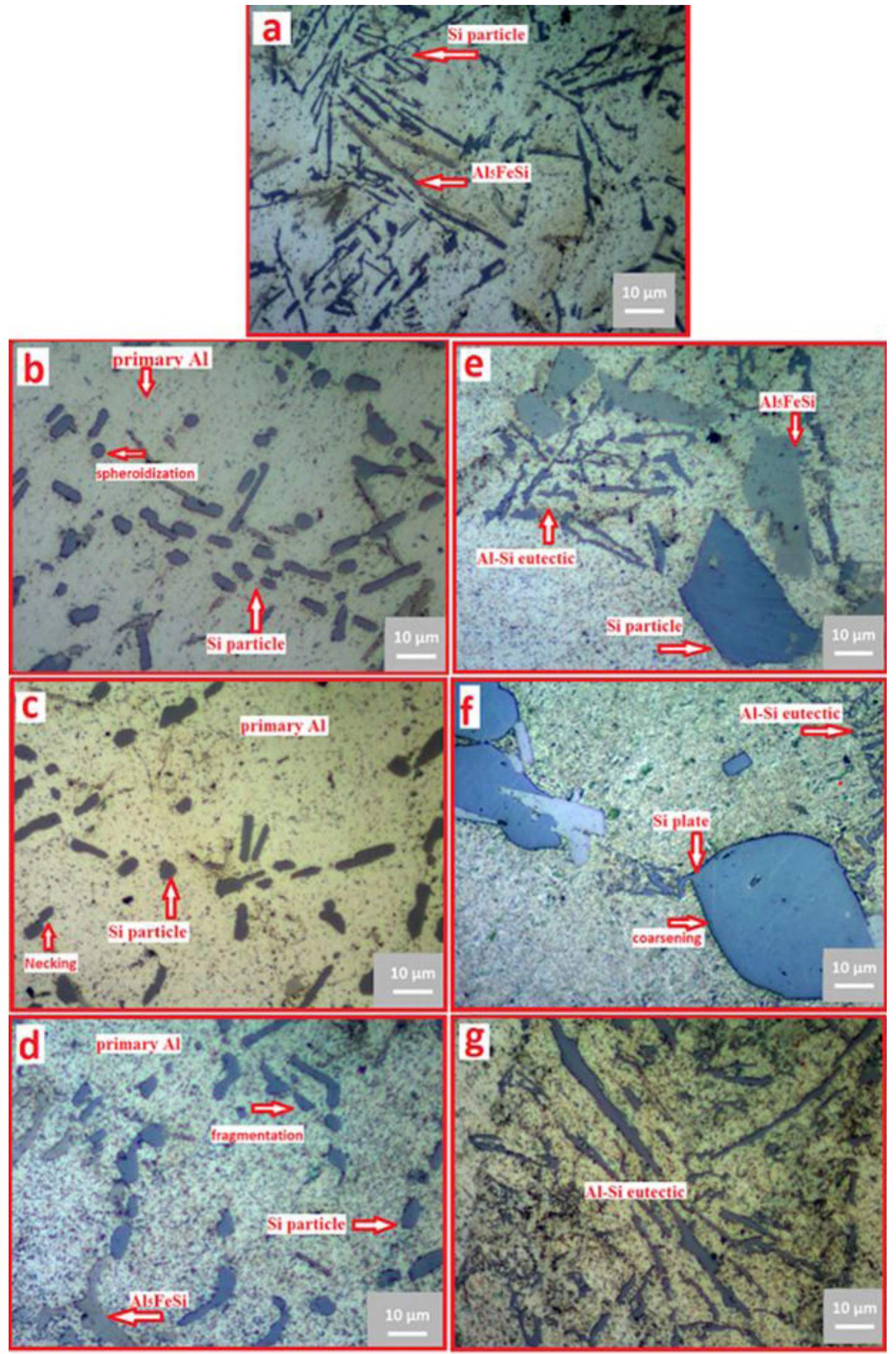

Figure 3. Optical microscopy images of Al-Si-Cu alloy (a) as-cast sample (b-d) samples under solution treatment at $500^{\circ} \mathrm{C} / 6 \mathrm{~h}$ followed by ageing treatment. (e-g) samples under solution treatment at $540^{\circ} \mathrm{C} / 6 \mathrm{~h}$ followed by ageing treatment. 
$\mathrm{Al}_{5} \mathrm{FeSi}$ and $\mathrm{Al}_{15}(\mathrm{FeMn})_{3} \mathrm{Si}_{2}$ were also identified in the samples. Microstructural evolution shows, as discussed previously, that the detrimental needle-like particles, present in the ascast sample, turns into globular shape particles after solution heat treatment, performed at $500^{\circ} \mathrm{C}$. The efficiency of surface diffusion on the fragmentation of eutectic Si particles depends strongly on the existence of interface defects between the $\mathrm{Si}$ particles and primary $\mathrm{Al}$ phase during solution treatment ${ }^{28}$. The change of Si particles morphology occurs when the eutectic structure is exposed to a thermal treatment, in which the temperature is enough to activate shape perturbations in the Si particle, eventually leading to the fragmentation into a series of nearly spherical particles. The overall mechanism indicated that the fragmentation of the needle-like particles was followed by spheroidization after solution treatment at $500^{\circ} \mathrm{C}$. Nevertheless, exaggerated growth occurred for solution treatment at $540^{\circ} \mathrm{C}$, resulting in the formation of the intermetallic $\mathrm{Al}_{15}(\mathrm{FeMn})_{3} \mathrm{Si}_{2}$ with plate shape, as illustrated in Figure 4c. This increase in the particles size is due to the higher diffusion coefficient, which resulted in the rise of the
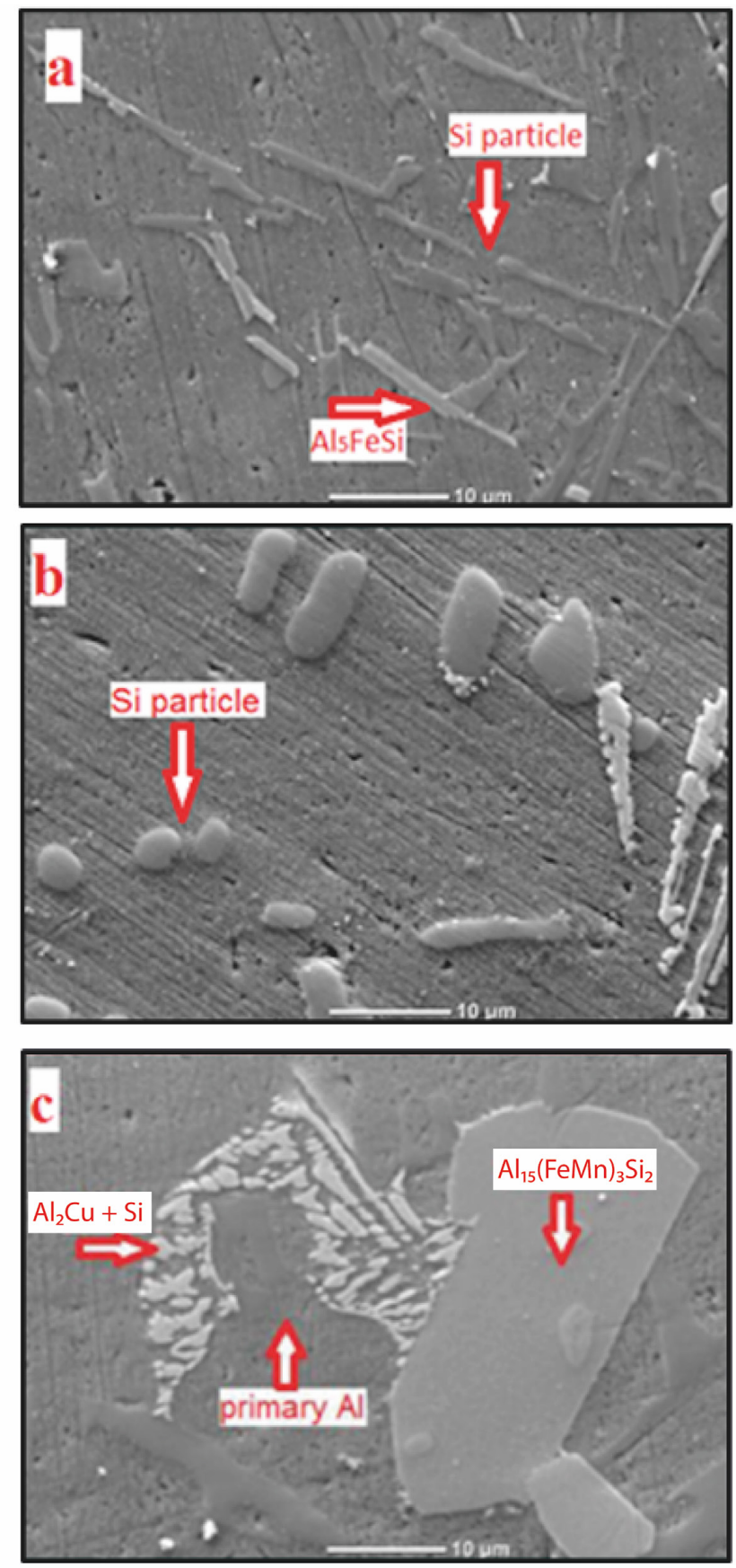
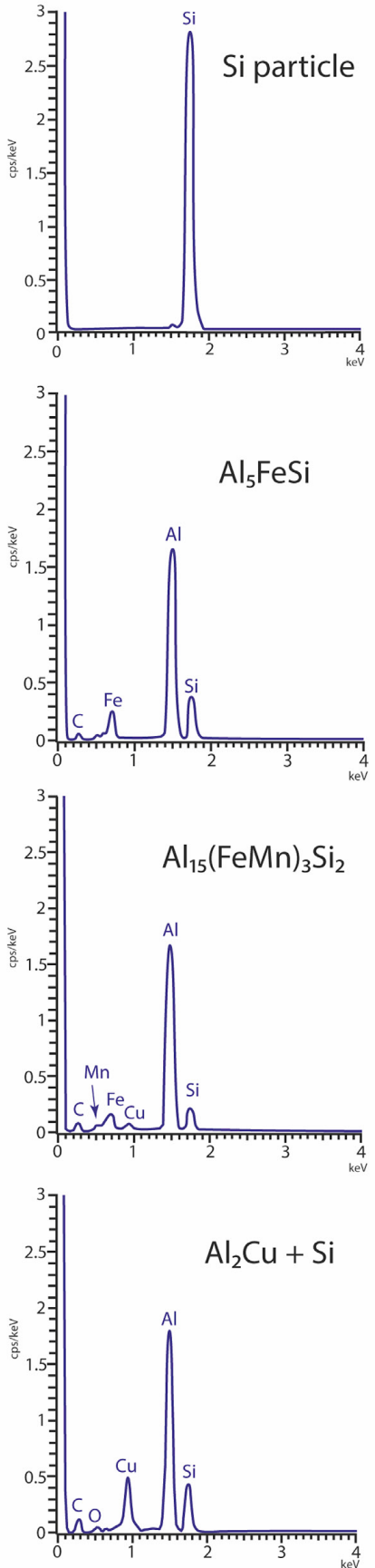

Figure 4. SEM images of the samples (a) as-cast sample (b) $500^{\circ} \mathrm{C} / 6 \mathrm{~h}$ and ageing at $160^{\circ} \mathrm{C} / 6 \mathrm{~h}$ (c) $540^{\circ} \mathrm{C} / 6 \mathrm{~h}$ and ageing at $210^{\circ} \mathrm{C} / 2 \mathrm{~h}$. EDS spectra for each microconstituent is shown in the right. 
coarsening rate, in comparasion to the spherodization rate. This is easily perceived when we compare the mean size of the particles under heat treatments at 500 and $540^{\circ} \mathrm{C}$. We also recall that the presence of intermetallic particles such as $\mathrm{Al}_{2} \mathrm{Cu}$ and $\mathrm{Al}_{5} \mathrm{FeSi}$ in the microstructure of Al-Si-Cu alloys after solution treatments and ageing were already reported in the literature ${ }^{41,42}$.

XRD analysis was also performed (Figure 5) and the observed peaks were in identified as Fe-rich intermetallics $\mathrm{Al}_{5} \mathrm{FeSi}$ and $\mathrm{Al}_{15}(\mathrm{FeMn})_{3} \mathrm{Si}_{2}$, as well as $\mathrm{Al}_{2} \mathrm{Cu}, \mathrm{Si}$ and $\mathrm{Al}$ phases.

The presence of intermetallic with Chinese script morphology on the microstructure of sample at $500^{\circ} \mathrm{C} / 6 \mathrm{~h}$ and ageing at $160^{\circ} \mathrm{C} / 6 \mathrm{~h}$ was also perceived and ilustrated in the Figure 6. EDS analysis indicated that Chinese Script is constituted by the intermetallic phase $\mathrm{Al}_{15}(\mathrm{FeMn})_{3} \mathrm{Si}_{2}$. Manganese present in the Al-Si alloys may contribute for the change in the morphology of Fe-intermetallic phases from lamellar to massive polyhedron ${ }^{43}$.

Figure 7 details the microstructure of the sample submitted to solution treatment at $540^{\circ} \mathrm{C} / 6 \mathrm{~h}$ and ageing at $190^{\circ} \mathrm{C} / 4 \mathrm{~h}$. EDS spectra, once more, helped to reveal the chemical composition of each microconstituent present in the material. The spectrum of each selected region indicated the presence of the Si particle (spectrum 1), Fe-intermetallics, such as $\mathrm{Al}_{15}(\mathrm{FeMn})_{3} \mathrm{Si}_{2}$ (spectrum 2) and $\mathrm{Al}_{5} \mathrm{FeSi}$ (spectrum 3), as well as $\mathrm{Al}_{2} \mathrm{Cu}+\mathrm{Si}$ (spectrum 4 ) distributed in the primary

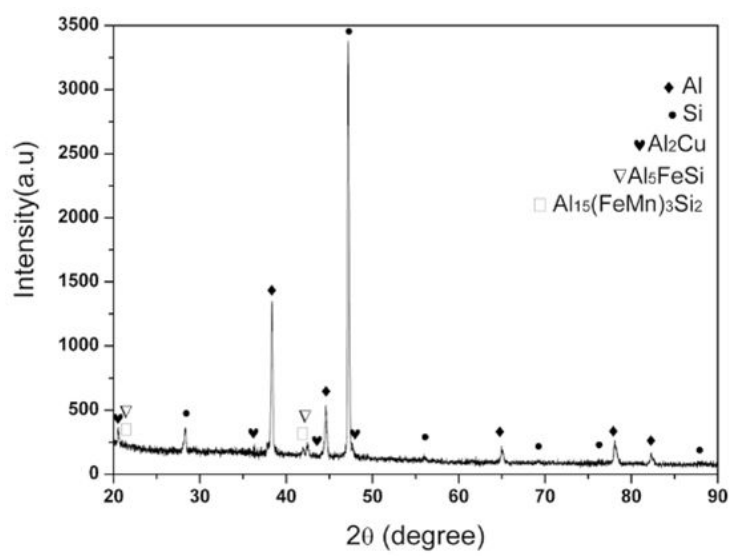

Figure 5. XRD pattern of Al-Si-Cu alloy after solution treatment at $540^{\circ} \mathrm{C}$.
Al matrix of the Al-Si alloy. These kinds of complex intermetallic compounds were already reported in similar alloys ${ }^{44,45}$. The presence of $\mathrm{Al}_{2} \mathrm{Cu}$ precipitate in aluminum alloys after solution treatments and ageing was also observed for $\mathrm{Al}$ alloys ${ }^{46,47}$. In this sense, alloying elements can promote nucleation and growth of complex intermetallic compounds in the microstructure of the alloy.

\subsection{Effect of heat treatment on microhardness of the Al-Si-Cu alloy}

The average hardness of the as-cast alloy and the samples submitted to solution/ageing heat treatments were investigated by Vickers microhardness measurements. The results are shown in the Figure 8. Samples submitted to solution treatment at $540^{\circ} \mathrm{C} / 6 \mathrm{~h}$ presented smaller hardness (100, 105 and $112 \mathrm{HV})$, when compared to samples at $500^{\circ} \mathrm{C} / 6 \mathrm{~h}$ (108, 109 and $\left.125 \mathrm{HV}\right)$. This result could be attributed to the softening of the Al-Si alloy due to the growth and morphological change of the primary $\mathrm{Al}$ grains from dendritic to globular shape and modification of the eutectic region. Consequently, the temperature rise of solution treatment contributed for a reduced effect of the pinning force, due to the dissolution of precipitates in the grain boundaries, leading to the growth of the primary $\mathrm{Al}$ grains and reduction of the hardness of the alloy.

Ragab et al. ${ }^{48}$ reported that solution temperatures above at $540^{\circ} \mathrm{C}$ could cause higher homogeinization of the microstructure, with probable full dissolution of the $\mathrm{Al}_{2} \mathrm{Cu}$ precipitates in regions of grain boundaries, decreasing the mechanical strength of the treated alloy. The hardness peak was obtained in samples aged at $190^{\circ} \mathrm{C}$ during $4 \mathrm{~h}$ for solution treatments at $500^{\circ} \mathrm{C}(125 \mathrm{HV})$ and $540^{\circ} \mathrm{C}(112 \mathrm{HV})$. This gradual increase in hardness for ageing temperatures ranging from 160 to $190^{\circ} \mathrm{C}$ may be associated to the formation of GP zones (Guinier-Preston), associated with the precipitattion of $\mathrm{Al}_{2} \mathrm{Cu}$ phase ${ }^{45}$. However, a drop in the microhardness value was observed for ageing temperatures above $190^{\circ} \mathrm{C}$ for both solution temperatures. This can be attributed to the higher thermodynamic stability, that resulted from the growth of the $\mathrm{Al}_{2} \mathrm{Cu}$ precipitate. Sjölander and Seifeddine ${ }^{49}$ reported simillar results in a $\mathrm{Al}-\mathrm{Si}-\mathrm{Cu}$ alloy, when submitted a heat treatment in the $\mathrm{T} 5$ condition. Barbosa et al. ${ }^{50}$ reported the occurrence of the maximum hardness in an intermediate ageing time, very similar to the observations made in this work.

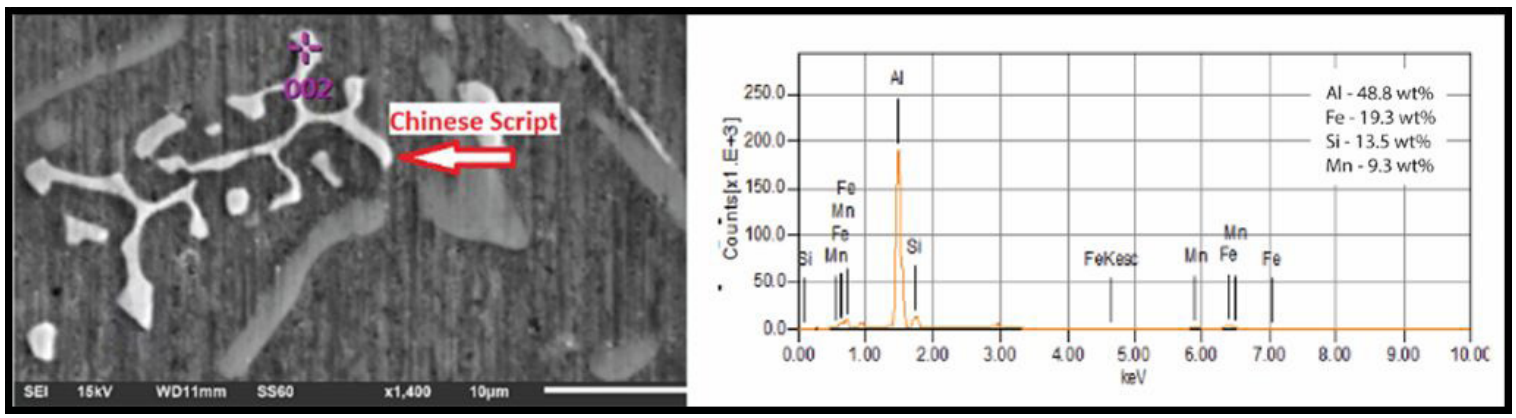

Figure 6. SEM images and EDS spectrum of the microstructure with presence of the intermetallic phase (Chinese script) correspondent the sample submitted at $500^{\circ} \mathrm{C}$ followed by ageing at $190^{\circ} \mathrm{C} / 4 \mathrm{~h}$. 

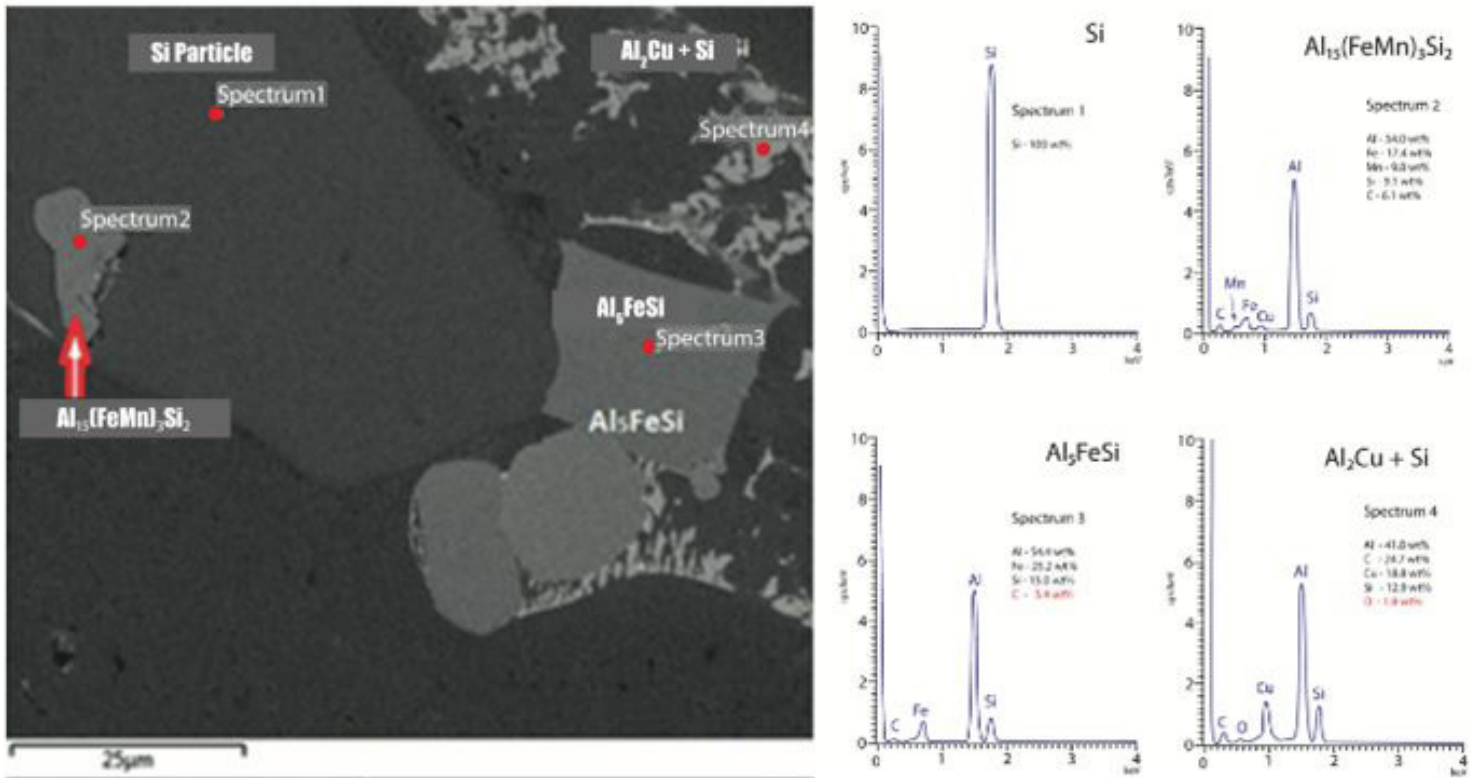

Figure 7. SEM images of the sample submitted to solution treatment at $540^{\circ} \mathrm{C}$ and ageing $190^{\circ} \mathrm{C} / 4 \mathrm{~h}$. EDS spectra of each microconstituent is shown on the right.

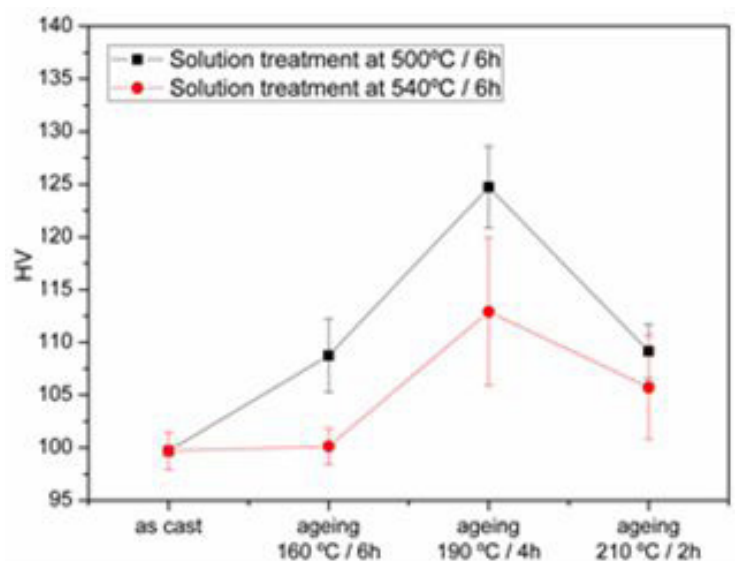

Figure 8. Results of microhardness obtained in the samples without and with heat treatments.

\subsection{Nanoindentention tests}

Differently form microhardness tests, nanaoindentation tests are able to access the mechanical behaviour of individual phases within the Al-Si alloys. In this sense, nanoindentation tests were used to measure nanohardness and determine elastic modulus of $\alpha-\mathrm{Al}, \mathrm{Al}_{5} \mathrm{FeSi}$ and $\mathrm{Si}$ particles microconstituents. Multiple tests were performed in order to obtain only indentation marks covering $100 \%$ of the particles.

Figure 9a shows load-displacement curves for the microcontituents present in the as-cast $\mathrm{Al}$ alloy. A maximum penetration depth of $\sim 945 \mathrm{~nm}$ occurred for Al matrix, indicating this is the softer phase among all analyzed microconstituents. The load-displacement curve of the
$\mathrm{Al}_{5} \mathrm{FeSi}$ intermetallic registered a maximum penetration depth of $\sim 799 \mathrm{~nm}$; maximum penetration depth for $\mathrm{Si}$ particle was $\sim 639 \mathrm{~nm}$. The plastic deformation caused by the indenter tip in each phase revealed that $\mathrm{Al}$ matrix has a greater capacity of elastic and plastic deformation, which was expected since soft phases present better mobility for dislocations. Discontinuities were also observed in the loading curves. These events are known as "pop-ins" and are more pronounced for brittle intermetallic phases, such as $\mathrm{Al}_{5} \mathrm{FeSi}$ and $\mathrm{Si}$ particles. Pop-in events were indicated by red and blue arrows on the loading curves of the as-cast sample presented in Figure 10a. The appearance of pop-ins in the loading curves is influenced by the homogeneous dislocation nucleation, as reported elsewhere ${ }^{46,47}$.

For the sample submitted to solution treatment at $500^{\circ} \mathrm{C} / 6 \mathrm{~h}$ and aged at $160^{\circ} \mathrm{C} / 6 \mathrm{~h}$, Figure $9 \mathrm{~b}$ shows that the Si particle presented the smallest penetration depth and a more pronounced elastic recovery, when compared with $\mathrm{Al}_{5} \mathrm{FeSi}$ intermetallic. These features are compatible with the high hardness value obtained for the Si particle $\left(\mathrm{H}_{\mathrm{IT}}=11.59 \pm 0.04 \mathrm{GPa}\right)$. In fact, Si particle also presented the smallest penetration depth $(\sim 362) \mathrm{nm}$ among all samples treated at $540^{\circ} \mathrm{C} / 6 \mathrm{~h}$, regardless of the conditions used for ageing treatments, as seen in Figure 10c. Unloading curves of the Si particles in heat treated samples also showed "elbows", also known as "pop-outs" phenomena. Pop-outs may be attributed to plastic deformation caused by dislocation activity, as well as pressure-induced phase transformation ${ }^{51,52}$. Nevertheless, cracks in the Si phases were also observed after unloading (Figure 10) and may also originate the observed pop-outs, also revealing the brittle behavior of this microconstituent.

The results of hardness obtained by nanoindetation measurements are summarized in Figure 11. 

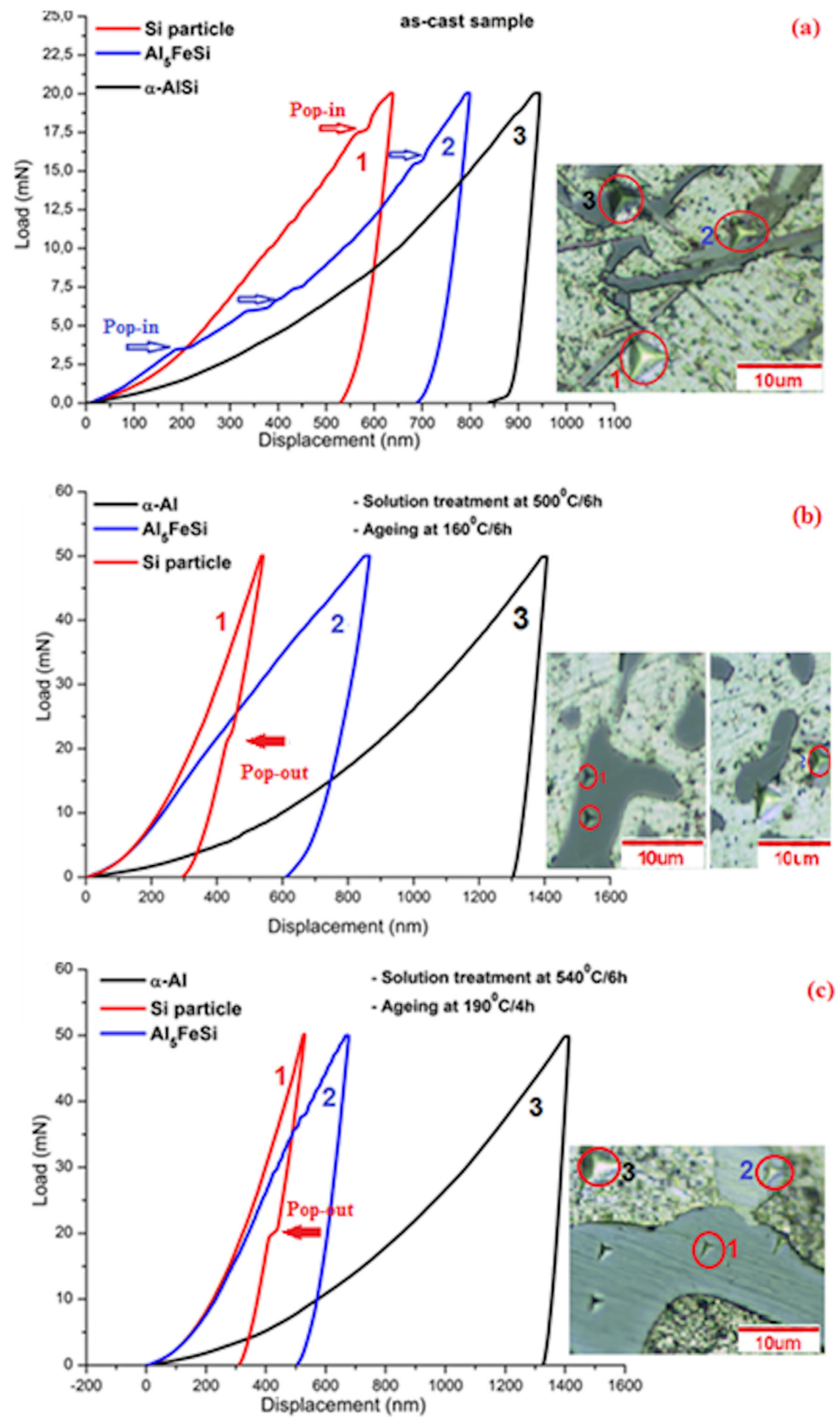

Figure 9. Load-displacement curves and indented surface microstructure of the $\mathrm{Al}-\mathrm{Si}-\mathrm{Cu}$ alloy (a) as-cast sample (b) $500^{\circ} \mathrm{C} / 6 \mathrm{~h}$ and ageing $160^{\circ} \mathrm{C} / 6 \mathrm{~h}$ (c) $540^{\circ} \mathrm{C} / 6 \mathrm{~h}$ and ageing at $190^{\circ} \mathrm{C} / 4 \mathrm{~h}$. 
Nanohardness of $\alpha$-Al phase presented small variations among the heat treated samples. However, a higher hardness $\left(\mathrm{H}_{\mathrm{IT}}=1.30 \pm 0.13 \mathrm{GPa}\right)$ was observed for the sample submitted to the solution treatment at $500^{\circ} \mathrm{C}$ and ageing at $190^{\circ} \mathrm{C} / 4 \mathrm{~h}$. This is also the sample that presented the smaller $\mathrm{Al}_{2} \mathrm{Cu}$ and $\alpha-\mathrm{Al}$ particles, as a consequence of particle fragmentation. The hardness of $\alpha$-Al phase presented a slight reduction in samples submitted to the solution treatment at $540^{\circ} \mathrm{C}$, as it was noted on the aged sample at $190^{\circ} \mathrm{C} / 4 \mathrm{~h}\left(\mathrm{H}_{\mathrm{IT}}=1.14 \pm\right.$ $0.03 \mathrm{GPa})$. This reduction in the hardness could be attibuted to the coarsenig of $\alpha$-Al grains and presence of $\mathrm{Al}_{2} \mathrm{Cu}$ eutectic regions. The smallest hardness for $\alpha-\mathrm{Al}$ phase was observed for the as-cast sample $\left(\mathrm{H}_{\mathrm{IT}}=1.08 \pm 0.01 \mathrm{GPa}\right)$. The values of hardness obtained for $\alpha-\mathrm{Al}$ by nanoindentation tests in room temperature are compatible with values of hardness obtained elsewhere ${ }^{46,47}$.

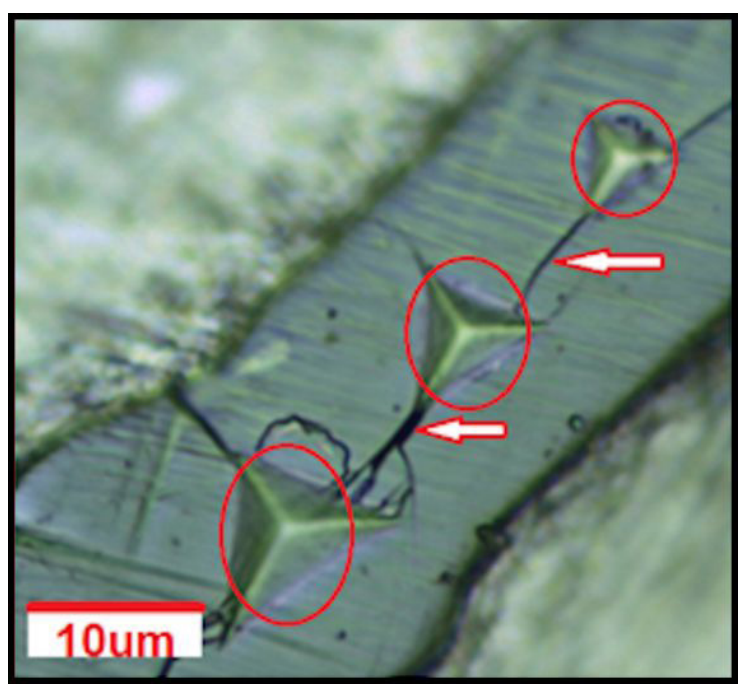

Figure 10. Occurrence of cracks on the Si particle after nanoindentation tests. Sample submitted to solution treatment at $540^{\circ} \mathrm{C} / 6 \mathrm{~h}$ and ageing at $210^{\circ} \mathrm{C} / 2 \mathrm{~h}$.

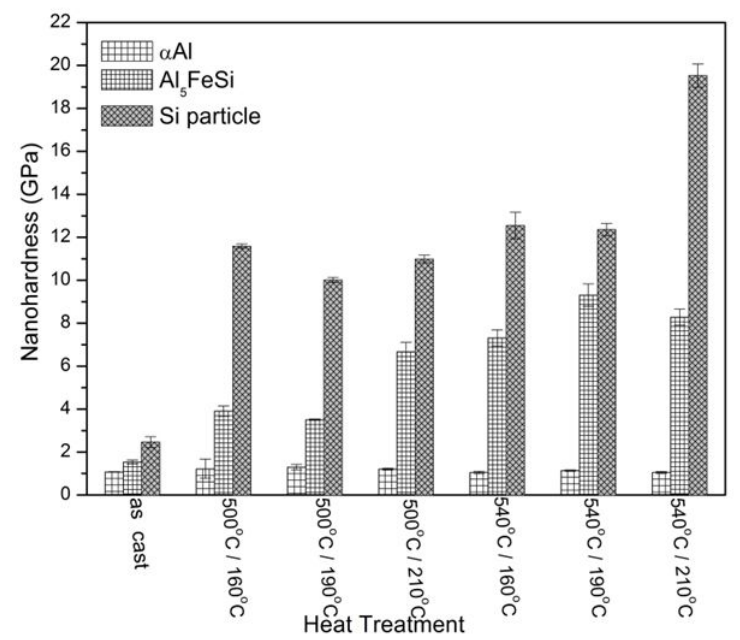

Figure 11. Hardness behavior for each relevant phase of the Al-Si$\mathrm{Cu}$ alloy obtained from nanoindentation tests.
The hardness peak obtained for the $\mathrm{Al}_{5} \mathrm{FeSi}$ intermetallic phase was $\left(\mathrm{H}_{\mathrm{IT}}=9.31 \pm 0.52 \mathrm{GPa}\right)$ for the sample under solution treatment at $540^{\circ} \mathrm{C} / 6 \mathrm{~h}$ and ageing at $190^{\circ} \mathrm{C} / 4 \mathrm{~h}$. The Si particle presented a higher hardness value $\left(\mathrm{H}_{\mathrm{IT}}\right.$ $=19.53 \pm 0.54 \mathrm{GPa})$ for the treated sample at $540^{\circ} \mathrm{C} / 6 \mathrm{~h}$ and ageing at $210^{\circ} \mathrm{C} / 2 \mathrm{~h}$. The increase of the hardness of the $\mathrm{Si}$ particle and $\mathrm{Al}_{5} \mathrm{FeSi}$ intermetallic compound may be attributed to the intense diffusion process acting in the conversion of small particles to big platellets $\left(\mathrm{Al}_{5} \mathrm{FeSi}\right)$ and disks (Si) during the solution treatment at $540^{\circ} \mathrm{C} / 6 \mathrm{~h}$. The formation of big Si particles discs in the eutectic region indicates that coarsening occurred via Ostwald Ripening growth mechanism ${ }^{27}$.

Elastic modulus from each phase could also be retrieved from nanoindentaion tests. Results showed that elastic modulus of the $\mathrm{Al}, \mathrm{Al}_{5} \mathrm{FeSi}$ and $\mathrm{Si}$ increased for almost all the samples submitted to solution / ageing heat treatments, as shown in Figure 12. Among the phases submitted to the indentation tests, $\alpha$-Al presented the smallest elastic modulus value for the heat treated samples $\left(\mathrm{E}_{\mathrm{IT}}=105\right.$ $\pm 3 \mathrm{GPa}$ for the sample treated at $540^{\circ} \mathrm{C}$ and ageing at $\left.210^{\circ} \mathrm{C} / 4 \mathrm{~h}\right)$. However, a small variation of the elastic modulus values of $\alpha-\mathrm{Al}$ phase was observed among the treated samples. $\mathrm{Al}_{5} \mathrm{FeSi}$ intermetallic phase presented an intermediary value of elastic modulus $\left(\mathrm{E}_{\mathrm{IT}}=182 \pm 5 \mathrm{GPa}\right.$, for the heat treated sample at $540^{\circ} \mathrm{C}$ and ageing at $160^{\circ} \mathrm{C} / 6 \mathrm{~h}$ ); $\mathrm{Si}$ particles showed the highest elastic modulus among all microconstituents $\left(\mathrm{E}_{\mathrm{IT}}=267 \pm 15 \mathrm{GPa}\right.$, for the treated sample at $540^{\circ} \mathrm{C}$ with ageing at $210^{\circ} \mathrm{C} / 2 \mathrm{~h}$ ). The elastic modulus profiles of different phases revealed that the $\mathrm{Si}$ particle presented higher elastic modulus than $\mathrm{Al}_{5} \mathrm{FeSi}$ intermetallic in all heat treatment conditions.

It was also noted that the $\mathrm{Al}_{5} \mathrm{FeSi}$ intermetallic and $\mathrm{Si}$ particles within the samples submitted to solution treatment at $540^{\circ} \mathrm{C}$ possess higher elastic modulus when compared with the samples heat treated at $500^{\circ} \mathrm{C}$. This clearly reveals that the elastic modulus of the microconstituents is sensitive to the morphological changes promoted by the solution treatment.

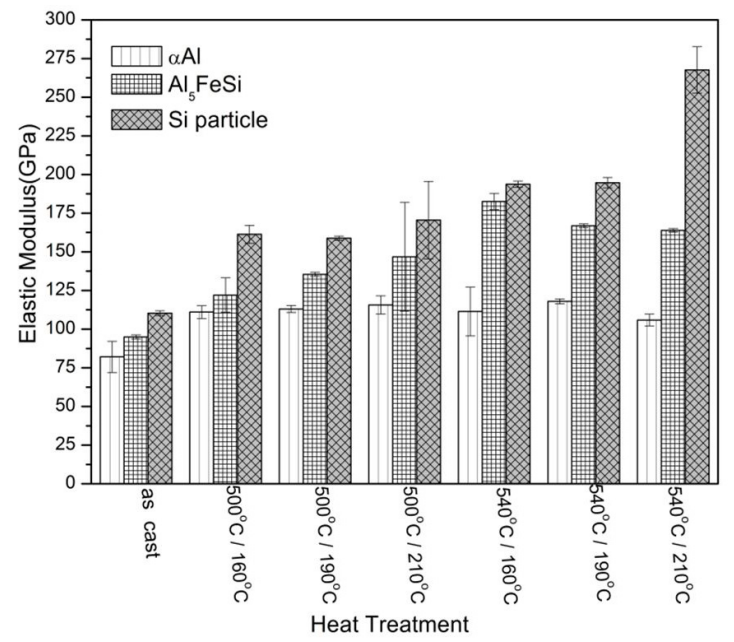

Figure 12. Elastic Modulus behavior for each relevant phase of the Al-Si-Cu alloy obtained from nanoindentation tests. 


\section{Conclusions}

The effect of processing parameters employed during solution and ageing treatments on the microstructural evolution and hardness properties was investigated and the conclusions may be drawn:

- As-cast Al-Si alloy revealed a microstructure composed of primary dendritic $\alpha$-Al matrix grains, along with $\mathrm{Al}-\mathrm{Si}$ eutectic region as well as $\mathrm{Al}_{5} \mathrm{FeSi}$, $\mathrm{Al}_{15}(\mathrm{FeMn})_{3} \mathrm{Si}_{2}$ and $\mathrm{Si}$ particles distributed on the $\alpha$-Al matrix.

- Small coarsening of the dendritic grains was observed in samples submitted to solution treatment at $500^{\circ} \mathrm{C} / 6 \mathrm{~h}$ and ageing at $160^{\circ} \mathrm{C} / 6 \mathrm{~h}$, $190^{\circ} \mathrm{C} / 4 \mathrm{~h}$ and $210^{\circ} \mathrm{C} / 2 \mathrm{~h}$ presented small. Also, modification of $\mathrm{Si}$ particles from acicular to globular morphologies was observed, probably due to the presence of fragmentation and coarsening mechanisms.

- Solution treatment at $540^{\circ} \mathrm{C} / 6 \mathrm{~h}$ promoted the growth and spheroidization of the primary $\mathrm{Al}$ grains and modifications of the morphology of the eutectic $\mathrm{Al}-\mathrm{Si}$ in eutectic region. Grains coarsening were observed in all ageing treatments. Disk shape Si particles, platelets of $\mathrm{Al}_{5} \mathrm{FeSi}$ and $\mathrm{Al}_{2} \mathrm{Cu}$ precipitates were observed.

- Microhardness tests showed an increase of vickers hardness in all treated samples for both solution treatment and ageing; higher hardness valeus were found for ageing treatments performed at $190^{\circ} \mathrm{C} / 4 \mathrm{~h}$. Softening of the Al-Si alloy occurred in the samples submitted to the solution treatment at $540^{\circ} \mathrm{C} / 6 \mathrm{~h}$ in all ageing conditions.

- Small pop-in features were observed on the loaddisplacement curves, indicating the presence of brittle phases, such as $\mathrm{Al}_{5} \mathrm{FeSi}$ intermetallic compound and Si particles.

- Mechanical stiffnes of Al-Si alloy was evaluated by nanoidentation tests and the results showed that heat treatments promoted the increase of the hardness and elastic modulus in $\mathrm{Al}_{5} \mathrm{FeSi}$ intermetallic compound and Si particles.

- $\quad$ Si particles exhibited the highest elastic modulus $\left(\mathrm{E}_{\mathrm{IT}}=267 \mathrm{GPa}\right)$ among all analysed microconstituents, independently of the heat treatment conditions.

In summary, we could demonstrate how the conditions used for solution and ageing treatments affect each individual phase in the microstructure of the Al-Si alloy. Nanoindentation technique proved to be a powerful tool to access the role that each microconstituent play on the determination of the overall mechanical properties of the alloy. We remark that studies comprising the employment of nanoindentation techniques along with the traditional tests used to characterize the macromechanical properties of Al alloys are not common in the literature. Nevertheless, the knowledge that can be obtained from the detailed investigation of each microconstituent in the alloy may be used to improve the alloy manufacturing in order to achieve superior mechanical properties for the engineering of advanced materials.

\section{Acknowledgements}

The authors thank FAPESP (Grant: 2016/11873-3) by the financial support regarding the maintenance of thermal analysis equipament belonging to Laboratório de Processamento e Caracterização de Materiais from Faculdade de Tecnologia de São Paulo (FATEC-SP).

\section{References}

1. Osório WR, Garcia LR, Goulart PR, Garcia A. Effects of eutectic modification and $\mathrm{T} 4$ heat treatment on mechanical properties and corrosion resistance of an $\mathrm{Al}-9 \mathrm{wt} \% \mathrm{Si}$ casting alloy. Mater Chem Phys. 2007;106(2-3):343-9. http://dx.doi.org/10.1016/j. matchemphys.2007.06.011.

2. Roy MJ, Maijer DM. Response of A356 to warm rotary forming and subsequent T6 heat treatment. Mater Sci Eng A. 2014;611:223-33. http://dx.doi.org/10.1016/j.msea.2014.05.088.

3. Pramod SL, Ravikirana, Rao AKP, Murty BS, Bakshi SR. Effect of Sc addition and T6 aging treatment on the microstructure modification and mechanical properties of A356 alloy. Mater Sci Eng A. 2016;674:438-50. http://dx.doi.org/10.1016/j. msea.2016.08.022.

4. Yan H, Chen F, Li Z. Microstructure and mechanical properties of AlSi10Cu3 alloy with $(\mathrm{La}+\mathrm{Yb})$ addition processed by heat treatment. J Rare Earths. 2016;34(9):938-44. http://dx.doi. org/10.1016/S1002-0721(16)60118-7.

5. Hwang JY, Doty HW, Kaufman MJ. The effects of Mn additions on the microstructure and mechanical properties of $\mathrm{Al}-\mathrm{Si}-\mathrm{Cu}$ casting alloys. Mater Sci Eng A. 2008;488(1-2):496-504. http:// dx.doi.org/10.1016/j.msea.2007.12.026.

6. Ragab KA, Samuel AM, Al-Ahmari AMA, Samuel FH, Doty HW. Influence of fluidized sand bed heat treatment on the performance of Al-Si cast alloys. Mater Des. 2011;32(3):117793. http://dx.doi.org/10.1016/j.matdes.2010.10.023.

7. LI K, Zhang J, Chen X, Yin Y, He Y, Guan R, Zhou J. Microstructure evolution of eutectic Si in Al-7Sibinary alloy by heat treatment and its effect on enhancing thermal conductivity. Mater Res Technol. 2020;9(4):8780-6.

8. Wang J, Zhu J, Liu Y, Peng H, Su X. Effect of spheroidization of eutectic Si on mechanical properties of eutectic Al-Si alloys. J Mater Res. 2018;144(12):1773-81. http://dx.doi.org/10.1557/ jmr.2018.144.

9. Samuel AM, Garza-Elizondo GH, Doty HW, Samuel FH. Role of modification and melt thermal treatment processes on the microstructure and tensile properties of Al-Si alloys. Mater Des. 2015;80:99-108. http://dx.doi.org/10.1016/j.matdes.2015.05.013.

10. Zhuo X, Liu Y, Wu C, Peng H, Wang J, Su X. Experimental investigation of the 600 and $800{ }^{\circ} \mathrm{C}$ sections of the Fe-MnSb system. J Alloys Compd. 2018;765:444-50. http://dx.doi. org/10.1016/j.jallcom.2018.06.186.

11. Amne Elahi M, Shabestari SG. Effect of various melt and heat treatment conditions on impact toughness of A356 aluminum alloy. Trans Nonferrous Met Soc China. 2016;26(4):956-65. http://dx.doi.org/10.1016/S1003-6326(16)64191-2.

12. Xu X, Deng Y, Chi Sh, Guo X. Effect of interrupted ageing treatment on themechanical properties and intergranular corrosion behavior of Al-Mg-Si alloys. J Mater Res Technol. 2020;9(1):230-41

13. Liu T, Karkkainen M, Nastac L, Arvikar V, Levin I, Brewer LN. Iron-rich intermetallics in high pressure die cast A383 aluminum alloys. Intermetallics. 2020;126:106814. http:// dx.doi.org/10.1016/j.intermet.2020.106814.

14. Summer F, Pusterhofer M, Grün F, Gódor I. Tribological investigations with near eutectic AlSi alloys found in engine vane pumps - Characterization of the material tribo-functionalities. Tribol Int. 2020;146:106236 
15. Souza FA, Marlo IAM, Costa O, Barros AS, Nascimento JM, Carvalho DB, et al. Unsteady-State horizontal solidification of an $\mathrm{Al}-\mathrm{Si}-\mathrm{Cu}-\mathrm{Fe}$ alloy: Relationship between thermal parameters and microstructure with mechanical properties/fracture feature. Met Mater Int. 2019;25:18-33

16. Tabibian S, Charkaluk E, Constantinescu A, Guillemot G, Szmytka F. Influence of process-induced microstructure on hardness of two Al-Si alloys. Mater Sci Eng A. 2015;646:190200. http://dx.doi.org/10.1016/j.msea.2015.08.051.

17. Chen CL, Richter A, Thomson RC. Mechanical properties of intermetallic phases in multi-component Al-Si alloys using nanoindentation. Inter. 2009;17:634-41.

18. Santos SL, Altobelli RA, Santos SF. Influence of injection temperature and pressure on the microstructure, mechanical and corrosion properties of a AlSiCu alloy processed by HPDC. Mater Des. 2015;88:1071-81.

19. Lattanzi L, Fabrizi A, Fortini A, Merlin M, Timelli G. Effects of microstructure and casting defects on the fatigue behavior of the high-pressure die-cast A1Si9Cu3(Fe) alloy. Procedia Structural Integrity. 2017;7:505-12. http://dx.doi.org/10.1016/j. prostr.2017.11.119.

20. Zhang Y, Zheng H, Liu Y, Shi L, Xu R, Tian X. Cluster-assisted nucleation of silicon phase in hypoeutectic Al-Si alloy with further inoculation. Acta Mater. 2014;70:162-73. http://dx.doi. org/10.1016/j.actamat.2014.01.061.

21. Oliver WC, Pharr GM. An improved technique for determining hardness and elastic modulus using load and displacement sensing indentation experiments. J Mater Res. 1992;7(6):156483. http://dx.doi.org/10.1557/JMR.1992.1564.

22. Luna IA, Marcha M H, Castro Román MJ, Escobedo Bocardo JC, Herrera Trejo M. Improvement of the tensile properties of an $\mathrm{Al}-\mathrm{Si}-\mathrm{Cu}-\mathrm{Mg}$ aluminum industrial alloy by using multi stage solution heat treatments. Mater Sci \& Eng A, 2013;561:1-6.

23. Souza FA, Costa MO, Magno IA, Nascimento JM, Silva AS, et al. Investigation on microstructural and microhardness evolution in as-cast and T6/heat-treated samples of a horizontally solidified AlSiCu alloy. J Mater Res Technol. 2019;8(5):5046-5052.

24. Timelli G, Capuzzi S, Fabrizi A. Precipitation of primary Ferich compounds in secondary $\mathrm{AlSi} 9 \mathrm{Cu} 3(\mathrm{Fe})$ alloys. J Therm Anal Calorim. 2016; 123:249-262.

25. Fabrizi A, Capuzzi S, De Mori A, Timelli G. Process. Metals (Basel). 2018;8(750):1-18.

26. Shivkumar S, Ricci S, Keller C, Apelian D. Effect of solution treatment parameters on tensile properties of cast aluminum alloys. J. Heat Treat. 1990;8(1):63-70. http://dx.doi.org/10.1007/ BF02833067.

27. El Sebaie O, Samuel AM, Samuel FH, Doty HW. The effects of mischmetal, cooling rate and heat treatment on the hardness of A319.1, A356.2 and A413.1 Al-Si casting alloys. Mater Sci Eng A. 2008;486(1-2):241-52. http://dx.doi.org/10.1016/j. msea.2007.09.011.

28. Lin YC, Luo SC, Huang J, Yin LX, Jiang XY. Effects of solution treatment on microstructures and micro-hardness of a Sr-modified Al-Si-Mg alloy. Mater Sci Eng A. 2018;725:53040. http://dx.doi.org/10.1016/j.msea.2018.04.049.

29. Costa TA, Dias M, Gomes LG, Rocha OL, Garcia A. Effect of solution time in $\mathrm{T} 6$ heat treatment on microstructure and hardness of a directionally solidified $\mathrm{Al}-\mathrm{Si}-\mathrm{Cu}$ alloy. J Alloys Compd. 2016;683:485-94. http://dx.doi.org/10.1016/j. jallcom.2016.05.099.

30. Sebaie OE, Samuel AM, Samuel FH, Doty HW. The effects of mischmetal, cooling rate and heat treatment on the eutectic $\mathrm{Si}$ particle characteristics of A319.1, A356.2 and A413.1 Al-Si casting alloys. Mater Sci Eng A. 2008;480(1-2):342-55. http:// dx.doi.org/10.1016/j.msea.2007.07.039.

31. Lin YC, Luo SC, Huang J, Yin LX, Jiang XY. Effects of solution treatment on microstructures and micro-hardness of a Sr-modified Al-Si-Mg alloy. Mater Sci Eng A. 2018;725:530-540.
32. Contatori C, Domingues Jr NI, Barreto RL, Lima NB, Vatavuk $\mathrm{J}$, Borges AAC, Almeida GFC, Couto AA. Effect of $\mathrm{Mg}$ and $\mathrm{Cu}$ on microstructure, hardness and wear on functionally graded Ale19Si alloy prepared by centrifugal casting. J. Mater Res Technol. 2020;9(6):15862-15873.

33. Cai Z, Zhang C, Wang R, Peng C, Qiu K, Wang N. Effect of solidification rate on the coarsening behavior of precipitate in rapidly solidified Al-Si alloy. Prog. Nat. Sci. 2016;26:391-7.

34. Wang J, Zhu J, Liu Y, Peng H, Sua X. Effect of spheroidization of eutectic Si on mechanical properties of eutectic Al-Si alloys. J Mater Res. 2018;33:1773-81.

35. Ji-Hua P, Xiao-long T, Jian-ting H, De-ying X. Effect of heat treatment on microstructure and tensile properties of A356 alloys. Trans Nonferrous Met Soc China. 2011;2:1950-6.

36. Menargues S, Martín E, Baile MT, Picas JA. New short T6 heat treatments for aluminium silicon alloys obtained by semisolid forming. Mater Sci Eng A. 2015;621:236-42. http://dx.doi. org/10.1016/j.msea.2014.10.078.

37. Moustafa MA, Samuel FH, Doty HW. Effect of solution heat treatment and additives on the microstructure of Al-Si (A413.1) automotive alloys. J Mater Sci. 2003;38(22):4507-22. http:// dx.doi.org/10.1023/A:1027333602276.

38. Han Y, Samuel AM, Doty HW, Valtierra S, Samuel FH. Optimizing the tensile properties of $\mathrm{Al}-\mathrm{Si}-\mathrm{Cu}-\mathrm{Mg}$ 319-type alloys: role of solution heat treatment. Mater Des. 2014;58:426-38. http:/ dx.doi.org/10.1016/j.matdes.2014.01.060.

39. Aguilera Luna I, Mancha Molinar H, Castro Román MJ, Escobedo Bocardo JC, Herrera Trejo M. Improvement of the tensile properties of an $\mathrm{Al}-\mathrm{Si}-\mathrm{Cu}-\mathrm{Mg}$ aluminum industrial alloy by using multi stage solution heat treatments. Mater Sci Eng A. 2013;561:1-6. http://dx.doi.org/10.1016/j.msea.2012.10.064.

40. Mohamed AMA, Samuel FH, Al kahtani S. Influence of Mg and solution heat treatment on the occurrence of incipient melting in Al-Si-Cu-Mg cast alloys. Mater Sci Eng A. 2012;543:22-34. http://dx.doi.org/10.1016/j.msea.2012.02.032.

41. Tabibian S, Charkaluk E, Constantinescu A, Guillemot G, Szmytka F. Influence of process-induced microstructure on hardness of two Al-Si alloys. Mater Sci Eng A. 2015;646:190200. http://dx.doi.org/10.1016/j.msea.2015.08.051.

42. Choi SW, Cho HS, Kang CS, Kumai S. Precipitation dependence of thermal properties for $\mathrm{Al}-\mathrm{Si}-\mathrm{Mg}-\mathrm{Cu}-(\mathrm{Ti})$ alloy with various heat treatment. J. Alloys and Compd., 2015, 647:1091-7.

43. Ma Z, Samuel E, Mohamed AMA, Samuel AM, Samuel $\mathrm{FH}$, Doty HW. Influence of aging treatments and alloying additives on the hardness of $\mathrm{Al}-11 \mathrm{Si}-2.5 \mathrm{Cu}-\mathrm{Mg}$ alloys Mater Des. 2010;31(8):3791-803. http://dx.doi.org/10.1016/j. matdes.2010.03.026.

44. Moustafa MA, Samuel FH, Doty HW. Effect of solution heat treatment and additives on the microstructure of Al-Si (A413.1) automotive alloys. J Mater Sci. 2003;38(22):4507-22. http:// dx.doi.org/10.1023/A:1027333602276.

45. Lumley RN, Polmear IJ, Groot H, Ferrier J. Thermal characteristics of heat-treated aluminum high-pressure die-castings. Scr Mater. 2008;58(11):1006-9. http://dx.doi.org/10.1016/j. scriptamat.2008.01.031.

46. Chen CL, Richter A, Thomson RC. Investigation of mechanical properties of intermetallic phases in multi-component Al-Si alloys using hot-stage nanoindentation. Intermetallic. 2010;18:499508.

47. Koch S, Abad MD, Renhart S, Antrekowitsch H, Hosemann P. A high temperature nanoindentation study of $\mathrm{Al}-\mathrm{Cu}$ wrought alloy. Mater Sci Eng A. 2015;644:218-24. http://dx.doi.org/10.1016/j. msea.2015.07.066.

48. Ragab KA, Samuel AM, Al-Ahmari AMA, Samuel FH, Doty HW. Influence of fluidized sand bed heat treatment on the performance of A1-Si cast alloys. Mater Des. 2011;32(3):117793. http://dx.doi.org/10.1016/j.matdes.2010.10.023. 
49. Sjölander E, Seifeddine $\mathrm{S}$. The heat treatment of $\mathrm{Al}-\mathrm{Si}-\mathrm{Cu}-\mathrm{Mg}$ casting alloys. J Mater Process Technol. 2010;210(10):1249-59. http://dx.doi.org/10.1016/j.jmatprotec.2010.03.020.

50. Barbosa CR, Machado GH, Azevedo HM, Rocha FS, Filho JC, Pereira AA, Otávio LR. Tailoring of Processing Parameters, Dendritic Microstructure, Si/ Intermetallic Particles and Microhardness in Ascast and HeatTreated Samples of A17Si0.3Mg Alloy. Met Mater Int. 2019;26:370-383.
51. Bhattacharya S, Alpas AT. Role of sliding-induced tribofilms on fracture of particles in aluminium-silicon alloys. Wear. 2013;301(1-2):707-16. http://dx.doi.org/10.1016/j. wear.2013.01.081.

52. Bhattacharya S, Riahi AR, Alpas AT. Indentation-induced subsurface damage in silicon particles of Al-Si alloys. Mater Sci Eng A. 2009;527(1-2):387-96. http://dx.doi.org/10.1016/j. msea.2009.08.052. 